\title{
Congenital Microcephaly
}

National Cancer Institute

\section{Source}

National Cancer Institute. Congenital Microcephaly. NCI Thesaurus. Code C128732.

A cong enital developmental disorder in which the circumference of the head is smaller than normal for the person's age and sex. 